Rose $\mathrm{nkr}$ a z , K. W., Aschefreies EiweiB. (Journal d. russ. phys.-chem. Ges. 38, 1906, $2-3$ V.)

Kristalle des Eiweißalbumins, dargestellt nach dem etwas veränderten Verfahren von Hof meister-Krüger, werden 6-10 mal umkristallisiert. Das Präparat wird in möglichst wenig Wasser gelōst und in einer Hülse von Schleicher \& Schüll gegen destilliertes Wasser dialysiert. Nach der möglichst vollständigen Entfernung des $\left(\mathrm{NH}_{4}\right)_{2} \mathrm{SO}_{4}$ wird die Flüssigkeit im Vakuumexsikkator auf ein Viertel ihres Volumens eingeengt und nochmals in eine kleinere Hülse dialysiert. Das a uf diese Weise dargestellte Präparat läbt beim Verbrennen keine Asche zurück und enthält auch keine nachweisbaren Spuren von $\left(\mathrm{NH}_{4}\right)_{2} \mathrm{SO}_{4}$. P. P. von Weimarn.

Herlitzka, A., Untersuchungen über Katalase. Ueber den Antagonismus zwischen Katalase und Peroxydase. (Atti della Reale Accademia dei Lincei, XV.)

Verf. richtete mehrere Reihen von je elf Reagensgläsern her und brachte in jedes Röhrchen jeder einzelnen Reihe fünf Tropfen einer alkoholischen Lösung von Guajakharz sowie in alle Robhrchen ein und derselben Serie zehn Tropfen einer Katalase-Lösung; in einer anderen Serie anstatt Katalase zehn Tropfen Wasser, in die elf Röhrchen aber jeder einzelnen Serie progressiv von $0-10$ Tropfen einer Lösung von seit bereits einem Jahre auskristallisiertem und katalytisch unwirksamem Hämoglobin. Schlieblich in sämtliche Röhrchen $10 \mathrm{ccm}$ Wasserstoffhyperoxydlösung.

Aus den hierbei erzielten Resultaten schlieBt Verf., daB zwischen der Wirkung der Katalase und der des Hămoglobins (oder überhaupt der Peroxydase) ein Antagonismus besteht bezüglich der Oxydation von Guajakharz durch Vermittlung des Hyperoxyds. Je stärker - innerhalb gewisser Grenzen - die Konzentration der Katalase ist, um so stärker muß auch die der Peroxydase zur Erzielung der Oxydation sein.

Dies ist der direkte Nachweis der von der Katalase auf die Peroxydase ausgeübten Schutzwirkung, welche in der Unschädlichmachung und Zerstörung der Superoxyde des Organismus besteht. Preti (Pavia).

Vand eve l de, A. J. J., Ueber Löslichkeitsverănderungen bei Milch- und Serumproteiden. (Bioch. Ztschr. VII, 396-400.)

Die Menge der făilbaren Proteide erleidet bei längerer Aufbewahrung von (Kolostral-) Milch und Blutserum bei $37,5^{\circ}$ unter Zusatz von Antisepticis eine Veränderung. Außer einer Verschiebung im Verhältnis der einzelnen Friktionen findet sich bei der Milch eine Abnahme der totalen Menge der fällbaren Proteide (also eine Proteolyse), bei dem Serum dagegen eine Erhöhung der Gesamtmenge fällbarer Proteide, so dab man hier an einen "Kondensations " Prozeb denken kann.

H. Aron.

Morochowitz, L., Das Globulin der koagulierbaren Substanz des Blutes. (Le Physiol. Russe, Bd. IV, 1906, S. 171-230.)

Derselbe, Verhalten des Globulins zu den Salzen. (Ebendort, 1906, S. 231-270.)

In diesen beiden in deutscher Sprache abgefaßten Abhandlungen wird neben zahlreichen eigenen Versuchen eine umfassend erscheinende Zusammenstellung des über die Blutgerinnung in der Literatur niedergelegten Materials gegeben. Die Arbeit ist ausgezeichnet durch zahlreiche Tabellen und enthält mancherlei Einzelheiten, die auch dem nicht physiologischen Kolloidchemiker von Interesse sein können.

\section{Dr. Schade.}

Bierry, H., Ueber die Wirkung der Amylase des Pankreas-Saftes und ihre Aktivierung durch den Magensaft. (Compt. rend. Bd. 146 von 1908 , S. 417 - 419.)

Der Pankreas-Saft des Hundes schreibt seine Alkalität fast ausschließlich dem Natriumkarbonat zu. Sie ist nicht nur von einem Tiere zum andern verschieden, sondern wechselt auch bei demselben Tier, ist aber gewöhnlich von der Ordnung einer $1 / 8$ norm. Sodalösung. Verfasser hat nun die Wirkung des Pankreas-Saftes auf Stärkekleister in alkalischer, neutraler und saurer Umgebung studiert und gezeigt, daB die Amylopektinase des Pankreas-Saftes eine sehr starke verflüssigende Wirkung auf den Stărkekleister besitzt, daB aber bei sehr schwachen Dosen des Saftes geringe Mengen von Säure (Salzsäure), wie sie auch der Magensaft liefert, eine erheblichere Wirkung des Pankreas-Saftes auslösen, als es ohne die Gegenwart der Säure der Fall ist. Einige Bemerkungen über die Beständigkeit der Amylase unter verschiedenen Bedingungen und Erörterungen über physiologische Zusammenhänge schließen sich an.

\section{E. $M$.}

Gessard, C., und Wolff, J., Ueber das Antiamylase - Serum. (Compt, rend. Bd. 146 von 1908 , S. $414-416$.)

Die Verfasser besprechen das Serum behandelter Kaninchen, das imstande ist, die Wirkung des Malzextraktes auf die Verzuckerung löslicher Stärke zu verhindern, geben die ange- 